\title{
The role of occult spinal malformation and upper urinary tract deterioration in children with intractable voiding dysfunction
}

\author{
Dirençli işeme fonksiyon bozukluğu olan çocuklarda üst üriner sistem hasarı ve gizli spinal \\ disrafizmin etkisi
}

Yılören TANIDIR, Tarık Emre ŞENER, Çağrı Akın ŞEKERCİ, Ahmet ŞAHAN, Yaşar BAYRI, Bahattin TANRIKULU, İlker TINAY, Harika ALPAY, Tufan TARCAN, Ferruh ŞIMSSEK, Cem AKBAL

\begin{abstract}
Objectives: To evaluate the presence of upper urinary tract deterioration (UUTD) and accompanying pathologies in children treated with the diagnosis of non-neurogenic bladder-sphincter dysfunction (NNBSD).

Patients and Methods: We retrospectively reviewed the medical records of 316 consecutive patients with NNBSD who were treated. All cohort were grouped into two: Group I (Treatment success; $n=284$ ), Group II (Treatment failure with any form of occult spinal pathology; $n=32$ ). Thirty-four children with treatment-failure and normal magnetic resonance imaging (MRI) findings were excluded. Groups were compared for pre- and posttreatment pediatric lower urinary tract symptom score (PLUTSS), presence of UUTD and urodynamic findings.
\end{abstract}

Results: The mean PLUTSS was significantly less in Group I compared with Group II at pre-treatment and 3 months thereafter the initial treatment $(12.20 \pm 5.90$ and $5.20 \pm 4.90$ vs $20.3 \pm 2.14$ and $18 \pm 3.4$, respectively $\mathrm{p}<0.01$ ). The mean cystometric capacities and detrusor leak point pressure (DLPP) of Group II prior to initial treatment and after 6 months of the untethering surgery were found

Yılören Tanıdır, Tarık Emre Şener, Çağrı Akın Şekerci, Ahmet Şahan, İlker Tınay, Tufan Tarcan, Ferruh Şimşek, Cem Akbal

Department of Urology, School of Medicine, Marmara University Hospital, Pendik, Istanbul, Turkey

e-mail:cakbal@gmail.com

Yaşar Bayrı, Bahattin Tanrıkulu

Department of Neurosurgery, School of Medicine, Marmara University Hospital, Pendik, Istanul, Turkey

Harika Alpay

Sub-department of Pediatric Nephrology, Department of Child Health and Pediatrics, School of Medicine, Marmara University Hospital, Pendik, Istanbul, Turkey

Submitted/Gönderme: 03.08 .2016

Accepted/Kabul: 02.09.2016 to be 194, $267 \mathrm{~mL}$ and 28, $12 \mathrm{~cm} \mathrm{H2O}$, respectively $(\mathrm{p}<0.05)$. Presence of UUTD was significantly correlated with DLPP $>20 \mathrm{~cm}$ $\mathrm{H} 2 \mathrm{O}$ and presence of vesicoureteral reflux (VUR).

Conclusion: UUTD in NNBSD is more common in children with occult spinal pathology, than in those without.

Keywords: Non-neuropathic bladder sphincter dysfunction, Upper urinary tract deterioration, Symptom score

ÖZ

Amaç: Nörojenik olmayan mesane-sfinkter fonksiyon bozukluğu (NOMSFB) tanısıyla tedavi edilen çocuklarda üst üriner sistem hasarı (ÜÜSH) ve eşlik eden patolojilerin araştırılmasıdır.

Hastalar ve Yöntemler: NOMSFB nedeniyle kliniğimizde tedavi edilen 316 çocuğun tıbbi kayıtları retrospektif olarak incelendi. Çocuklar, tedavi yanıtına ve magnetic resonans görüntüleme (MRG) bulgularına göre iki gruba ayrıldılar: Grup I (Tedaviye yanıt verenler; $n=284$ ) ile Grup II (Tedaviye dirençli olup, lomber MRG'sinde gizli spinal disrafizm bulgusu olanlar; $\mathrm{n}=32$ ). Tedaviye dirençli olup lomber MRG'sinde patoloji saptanmayan 34 çocuk çalışma dışı bırakıldı. Gruplar tedavi öncesi ve sonrası semptom skoru (SS), ÜÜSH ile ürodinami bulguları açısından karşılaştırıldı.

Bulgular: Tedavi öncesi dönemde ve tedavi başladıktan üç ay sonra, Grup I'in ortalama SS'si Grup II'ye göre anlamlı olarak düşük saptandı (sırasıyla 12,20 $\pm 5,90$ ve 5,20 \pm 4,90 karşın 20,3 $\pm 2,14$ ve $18 \pm 3,4 ; \mathrm{p}<0.01$ ). Grup II'nin başlangıç tedavisi öncesi ortalama sistometrik kapasitesi ve detrüsör kaçırma anı basıncı (DKAB) sirasiyla $194 \mathrm{ml}$ ve $28 \mathrm{~cm} \mathrm{H} 2 \mathrm{O}$ olarak saptand. Grup II'nin gergin omurilik onarımını takip eden altıncı ayda ortalama sistometrik kapasite ve ortalama DKAB sirasiyla $267 \mathrm{ml}$ ve 12 cmH2O olarak saptand1. ÜÜSH varlığı ile DKAB'ın $20 \mathrm{cmH} 2 \mathrm{O}$ üzeri olması ve vezikoüreteral reflü varlığı arasında anlamlı ilişki bulundu.

Sonuç: NOMSFB'da ÜÜSH, gizli spinal disrafizm varlığında daha sık görülür.

Anahtar kelimeler: Nörojenik olmayan mesane-sfinkter fonksiyon bozukluğu, Üst üriner sistem hasarı, Semptom skoru 


\section{Introduction}

Non-neurogenic bladder-sphincter dysfunction (NNBSD) is a frequently seen pathology in daily clinical practice of pediatric urology. Functional urinary incontinence and upper urinary tract deterioration (UUTD) are the most important complications of untreated NNBSD [1-4]. There seems to be a strong association between NNBSD and recurrent urinary tract infection (UTI) with or without accompanying vesicoureteral reflux (VUR) [2-4]. Treatment of NNBSD is essential in the management of recurrent UTI and VUR, as this prevents kidney damage $[5,6]$.

Dysfunctional voiding (DV), overactive bladder (OAB), and underactive bladder (UAB) are the main clinical outcomes of NNBSD [3]. Children with NNBSD who fail to respond to initial treatment should undergo a series of clinical study including urodynamics and lumbosacral magnetic resonance imaging (MRI) for the assessment of any occult spinal pathology $[6,7]$. Afshar et al., reported that in a population of 73 NNBSD patients, 3 of $35(8.6 \%)$ that failed in medical management had occult pathology [8]. Spinal dysraphism occurs in two forms: an open form named spina bifida aperta, and a closed form named spina bifida occulta. Either form of spinal deformity may feature as a progressive form of neurological deterioration called tethered cord syndrome which will finally need a neurosurgical intervention. MRI can be used to differentiate such neurologic abnormalities in patients with spinal dysraphism [9].

Generally UUTD with lower urinary tract dysfunction (LUTD) is related to tethered cord, thus one can expect similar predisposing factors for UUTD like in NNBSD [7]. Such factors include UTI, ongoing VUR, a high bladder filling and/or voiding pressure, and discoordinated voiding.

The aim of the current study was to evaluate the presence of UUTD and the related conditions in patients who have received an optimal treatment for NNBSD and yet were identified as having occult spinal pathology, both during treatment and during the early follow up period.

\section{Patients and Method}

\section{Study Population}

The study involved children who were diagnosed with NNBSD after admission to Marmara University, School of Medicine, Pediatric Urology Outpatient Clinic between November 2010 and June 2015. All cohort had one or more of the following symptoms: daytime and/or nighttime urinary incontinence, holding maneuvers, perceived incomplete emptying, urinary urgency, post-micturition dribble, weak stream, urinary hesitancy, intermittency, increased urinary frequency and UTI. Medical records of each patient were retrospectively reviewed. Categories of patients with NNBSD were identified (methods detailed below) and respective management protocols were applied. Children who responded to treatment for NNBSD were grouped as Group I. Those who did not respond to treatment underwent further testing, and study group was established based on these findings.

\section{Initial Diagnostics}

Pediatric Lower Urinary Tract Symptom Score (PLUTSS): This score was originally developed and validated by Akbal et al. [10] (Fig. 1). This instrument has been widely used for clinical assessment of LUTD and has also been applied in research studies [11, 12]. Similar tools have also been reported to be used to assess children with lower urinary tract symptoms [13]. The PLUTSS was administered to each child and to his/her parents at initial clinical evaluation period (pre-treatment) and repeated in every 6 months periods thereafter (post-treatment). For each patient, the pre-treatment PLUTSS and the 6 months of posttreatment PLUTSS were used for the study.

Other Tests: Each patient underwent a combined uroflowmetry assessment with electromyography (EMG). Total bladder capacity was calculated by adding voided urine volume to measured post-voiding residual urine volume under ultrasonography (USG), and was expressed as a percentage of age-expected bladder capacity [14]. Each patient also completed a bladder diary for two days with the recommended entries of International Children's Continence Society (ICCS) [14]. For the assessment of possible UUTD (i.e., hydronephrosis, parenchymal thinning, atrophy) each child underwent a routine imaging with USG. Those confirmed to have UTI and abnormal USG findings were further evaluated with voiding cystourethrography (VCUG). Grading of VUR was done according to the international classification $[15,16]$. Children with VUR underwent a dimercaptosuccinic acid (DMSA) scan and the results of the scan were summarized as either normal or scarring for the present study [17].

\section{Disease Categories and Management}

Based on initial diagnostics, patients with NNBSD were categorized as $\mathrm{OAB}, \mathrm{DV}$, or UAB. Patients with $\mathrm{OAB}$ were treated with timed voiding regimens, medications of 
anticholinergics and/or antibiotics. Anticholinergic treatment was done with oxybutynin in a dosage of $0.2 \mathrm{mg} / \mathrm{kg}$ via the enteral route. Patients with only nocturnal enuresis were advised to limit fluid intake in the evening and to urinate before going to bed. Those resistant to initial treatment for nocturnal symptoms were prescribed oral desmopressin (DDAVP) or alarm therapy, as recommended in pediatric urology guidelines [18].

Dysfunctional voiding was treated with timed voiding and positive reinforcement regimens, bowel regimens (including high daily fluid intake, a diet high in fiber, and stool softeners if necessary), biofeedback therapy, medications of alpha-blockers and/or antibiotics [19].

Underactive bladder was treated with clean intermittent catheterization and antibiotic prophylaxis. Bowel regimens were prescribed for patients with UAB who also had bowel problems.

\section{Additional Diagnostic Testing in Cases of No Response}

Children were treated for a minimum of 3 months before they were identified as non-responders. Based on pre- versus post-treatment PLUTSS results and discussion with patients and parents, "No response to treatment" was defined as any reduction of symptoms below 49\% [14]. All of these children named as non-responders underwent urodynamic and radiographic assessments.

Urodynamic Evaluation: Standard filling cystometry (AYMED, Locum Wireless Urodynamic System, Turkey) was performed with the patient in supine position, using a $6 \mathrm{~F}$ double-lumen urethral cystometry catheter and filling rate was taken as $5 \%$ to $10 \%$ of predicted bladder capacity $(($ age +1$) \times 30)$ per minute [14]. According to a report from the Standardization Committee of the International Continence Society [20] and ICCS [21], we calculated the maximum detrusor pressure ( $\mathrm{P}$ detmax, $\mathrm{cm}_{2} \mathrm{O}$ ), maximum cystometric capacity (MCC, ml), DLPP $\left(\mathrm{cmH}_{2} \mathrm{O}\right)$. Namely, The International Continence Society defines the DLPP as the value of the lowest detrusor pressure at which leakage occurs in the absence of abdominal pressure rise. The DLPP was measured by marking the lowest pressure at the moment when the urine seeped out from the urethral meatus.

Radiographic Evaluation: A spinal MRI was performed and any finding of conus medullaris below the lower endplate of the L2 vertebra, lipoma or thickening of the filum terminale, and/or vertebral anomalies was considered as abnormal [9].

\section{Statistical Analysis}

Data were analyzed using the Statistical Package for the Social Sciences (SPSS v. 20, IBM Corporation, NY, USA). Findings for pre-treatment and six-months-post-treatment SS were compared using the unpaired Student's $t$ test. Relationships between presence of UUTD and urodynamic parameters were assessed using Pearson correlation analysis. $P$ values $<0.05$ were considered significant.

\section{Results}

Of all 388 children a total of 34 children with NNBSD resistant to pharmacotherapy-urotherapy were excluded from the study, as they were candidates for other invasive treatment modalities (i.e., neuromodulation strategies, intradetrusor botulinium toxin A injection, or augmentation cystoplasty). Thirty-eight patients were lost to follow up. Group I patients $(n=284)$ consisted of NNBSD and treated with standard modalities and follow-up. Group II patients $(n=32)$ were children with NNBSD resistant to pharmacotherapy-urotherapy and were diagnosed as having any form of occult spinal pathology in further evaluation.

The mean follow-up time of the patients in the present study was $13.6 \pm 7.8$ months (range, 6-26 months). The mean ages of Groups I and II were not significantly different ( $8 \pm 2.1$ vs. $7 \pm 2.3$ years, respectively; $p>0.05$ ).

Of all the children in Group I, 97 had DV (34\%), 170 had OAB (60\%) and 17 had UAB (6\%). The mean PLUTSS results of the Group I patients at the pre-treatment period and 3 months thereafter was found to be $12.2 \pm 5.9$ and 5.2 \pm 4.9 , respectively.

Of all the children in Group II, 19 had DV (59\%) and 13 had OAB (41\%). The mean PLUTSS results of the Group II patients at the pre-treatment period and 3 months thereafter was found to be $20.3 \pm 2.1$ and $18 \pm 3.4$, respectively. The mean PLUTSS at the first $6^{\text {th }}$ month period following untethering surgery was found to be $12.2 \pm 1.8$. This final score was found to be significantly lower than the pretreatment PLUTSS $(\mathrm{p}<0.001)$, indicating an appropriate treatment for NNBSD.

\section{Additional Testing - Urodynamic Findings}

The mean cystometric capacities and mean DLPP of Group II prior to initial treatment was found to be $194 \mathrm{~mL}$ (min $45 \mathrm{~mL}$, max $302 \mathrm{~mL}$ ) and $28 \mathrm{~cm} \mathrm{H}_{2} \mathrm{O}\left(\min 4 \mathrm{~cm} \mathrm{H} \mathrm{H}_{2} \mathrm{O}\right.$, max $58 \mathrm{~cm} \mathrm{H}_{2} \mathrm{O}$ ), respectively. The mean cystometric capacities and the mean DLPP of Group II patients after 6 months of 
the untethering surgery was found to be $267 \mathrm{~mL}$ (min 145 $\mathrm{mL}, \max 335 \mathrm{~mL})$ and $12 \mathrm{~cm} \mathrm{H} 2 \mathrm{O}(\min 4 \mathrm{~cm} \mathrm{H} 2 \mathrm{O}, \max 20$ cm $\mathrm{H} 2 \mathrm{O})$, respectively $(\mathrm{p}<0.05)$.

\section{Upper Urinary Tract Deterioration}

In the initial evaluation period of Group II, of all patients, 12 (37.5\%) were found to have an UUTD on DMSA scanning. During the follow-up period $10(83.3 \%)$ of these 12 patients who had initial renal scars were seemed to be stabilized.

At initial assessment in Group II patients, 4 had VUR and 8 had a DLPP $>20 \mathrm{~cm} \mathrm{H}_{2} \mathrm{O}$. Presence of an UUTD was significantly correlated with two occasions; either having a DLPP $>20 \mathrm{cmH}_{2}$ O or having an accompanying VUR(Table II).

The proportion of patients with a history of recurrent UTI in Group II was significantly higher than that in Group I ( $76.5 \%$ vs. $31.2 \%$, respectively; $p<0.001$ ) (data not shown).

Table I: The initial relation of upper urinary tract deterioration (UUTD) and detrusor leak point pressure (DLPP) in Group II patients prior to treatment is shown

\begin{tabular}{|l|c|c|c|}
\hline & $\begin{array}{c}\text { UUTD } \\
\text { Absent (n) }\end{array}$ & $\begin{array}{c}\text { UUTD } \\
\text { Present (n) }\end{array}$ & $\begin{array}{c}\text { Total } \\
\text { (n) }\end{array}$ \\
\hline DLPP $>20 \mathrm{~cm} \mathrm{H}_{2} \mathrm{O}$ & 8 & 8 & 16 \\
\hline DLPP $<20 \mathrm{~cm} \mathrm{H}_{2} \mathrm{O}$ & 14 & 2 & 16 \\
\hline Total & 22 & 10 & 32 \\
\hline
\end{tabular}

Table II: The significance of having a correlation with an upper urinary tract deterioration prior to treatment is given for some instances like a detrusor leak point pressure (DLPP) $>20 \mathrm{~cm} \mathrm{H}_{2} \mathrm{O}$, presence of vesicoureteral reflux (VUR), and recurrent urinary tract infection (UTI). ( $\mathrm{r}$ value of Pearson Correlation is given with its statistical significance)

\begin{tabular}{|l|c|c|}
\hline & r value & p value \\
\hline DLPP $>20 \mathrm{~cm} \mathrm{H}_{2} \mathrm{O}$ & 0.459 & $<0.001$ \\
\hline VUR & 0.322 & $<0.01$ \\
\hline Recurrent UTI & 0.161 & $>0.05$ \\
\hline
\end{tabular}

\section{Discussion}

The findings of the present study, show a higher incidence of UUTD for patients with functional urinary incontinence as well as any occult spinal malformation who did not respond to treatment. Of all the patients with functional urinary incontinence $(\mathrm{n}=388)$ only $8.8 \% \quad(\mathrm{n}=34)$ did not respond to our initial treatment regimen, and of these patients with treatment failure, almost all $(n=32)$ were diagnosed as having tethered cord malformation. Considering the previous findings, it was advised to go for further radiologic imaging of spine by MRI in treatmentfailure of functional urinary incontinence, unless patients have normal urodynamic findings.

Pippi Salle et al., evaluated 32 consecutive children with complicated enuresis who were referred for neurosurgical evaluation [22]. They recorded normal spinal MRI findings in 21 patients $(91.3 \%)$, including 1 with a tethered cord and lipoma associated with a complex skeletal abnormality, and 1 with a nonprogressive, nonsurgical syrinx extending from T7 to T9 spinal levels. Only the case of lipoma required neurosurgical intervention. The authors concluded that MRI is of limited value in children with voiding dysfunction who have a normal neuroorthopedic assessment, and that this modality should be reserved for those with associated neuro-orthopedic findings or complex skeletal deformity on plain X-ray (Pippi Salle, Capolicchio et al. 1998). In contrast, Arikan et al., investigated 81 children with voiding dysfunction and reported pathologic findings in 17 (38.6\%) of 44 patients who had a normal neuro-orthopedic assessment [23]. They concluded that MRI of the lower spinal cord is a valuable tool for diagnosing occult spinal cord disorders, particularly in patients with the combination of voiding dysfunction refractory to conservative management and normal neurologic and orthopedic assessments.

Children who do not respond to behavioral or medical therapies for NNBSD should be considered candidates for invasive treatment modalities. Urinary incontinence is a very frequent problem encountered in pediatric urology outpatients. In our daily practice, most such children respond well to conservative methods such as timed voiding, behavioral modifications, biofeedbackcoupled pelvic floor exercises, and anticholinergic agents. Schulman et al., found that conservative approaches were successful in $45 \%$ of 280 children with urinary incontinence [24]. The mean age of those patients who responded at presentation was 8.5 years, and the mean follow-up time was 22 months. Another study by Curran et al., revealed a similar cure rate of $43 \%$ among 30 patients with idiopathic detrusor overactivity. These authors described "complete resolution" in $87 \%$; however, their definition of complete resolution included patients that were still on medication. Neither Schulman et al. nor Curran et al. were able to identify statistically significant clinical or urodynamic 
factors that predicted outcome [24, 25]. Weiner et al., reported a $60 \%$ treatment success rate after long-term follow up of children with daytime wetting [26].

Our study evaluated findings in children with tethered cord malformation. Such patients comprise a very small subset of many children who present with combination of treatment-resistant functional voiding problems and UUTD. Most patients who are resistant to treatment and have abnormal urodynamic findings have some degree of spinal pathology and should undergo MRI. These children require evaluation by a pediatric neurosurgeon [22, 23].

According to the current study, the treatment resistant disease should be followed carefully after untethering surgery because of continuing symptoms. In case of tethered cord malformation, the correction is effective for normalization of bladder dynamics. Hsihe et al., demonstrated that in children with abnormal urodynamics due to tethered cord malformation, untethering surgery may improve or even provides normalization of voiding dysfunction [27].

Stone et al., reported that children who presented with daytime wetting, uninhibited bladder contractions, and detrusor-sphincter dyssynergia were most likely to remain symptomatic after first line treatment. They offer that these patients might be considered for more aggressive alternative therapies, after a period of medical management [28]. In our series most of the treatment resistant children had DV scores different from the treatment responders' DV scores. In these cases main pathology was OAB.

The main factor for UUTD is having a reflux and high DLPP in our patient population. In our study, among patients who developed UUTD or patients with known but progressing UUTD, 4 had ongoing VUR and 8 had DLPP $>20 \mathrm{~cm} \mathrm{H}_{2} \mathrm{O}$ in Group II. Among these patients the mean grade of VUR before treatment was $2.7(\min 2 \max 4)$ in Group II and after treatment was 2.3 (min $1 \max 4$ ). It is well known that management of VUR in presence of disturbed bladder dynamics is a tough challenge. Seki et al., showed that factors such as low bladder compliance, presence of DSD and high maximum urethral closing pressure contributed to the incidence of VUR and were directly correlated with UUT damage [29].

Those patients also face a high number of UTI attacks and these attacks might affect the treatment response. Bael et al., described that urodynamics added little to the treatment of patients with $\mathrm{OAB}$ symptoms in the European
Bladder Dysfunction Study [30]. The pre-treatment urodynamic variable "detrusor overactivity throughout filling" correlated in only $33 \%$ of patients with the clinical diagnosis of urge syndrome. This finding implied that $67 \%$ of the children with complaints of frequency, urgency, daytime wetting and holding maneuvers did not have overactivity of the detrusor in the filling phase. After treatment the prevalence of detrusor overactivity still was $27 \%$ but two-thirds of these patients did not have detrusor overactivity before treatment, and in fact exhibited detrusor overactivity de novo [30]. It means that detrusor overactivity did not correlate with treatment outcome. Clearly, in urge syndrome urodynamic variables do not follow clinical symptoms. We assume that urgency and frequency are due to overactivity, and start specific treatment based on that assumption. The assumption may be right but urge syndrome and concomitant detrusor overactivity may just occur on provocation only, giving rise to complaints and the seeking of medical attention when coping mechanisms fail. Because of the above mentioned reasons, some of the patients in the Group II had symptoms after successful surgery and they needed additional treatment. The response period for those patients may last as we expected.

High detrusor leak point pressure is shown to be a risk factor for UUTD in children with spinal dysraphism. Values higher than $40 \mathrm{~cm} \mathrm{H}_{2} \mathrm{O}$ are proven to be a major contribution to UUTD [31]. Even values between 20 and $40 \mathrm{~cm} \mathrm{H}_{2} \mathrm{O}$ are shown to be more sensitive for predicting UUTD [32]. In our study, the DLPP of children above 20 $\mathrm{cm} \mathrm{H}_{2} \mathrm{O}$ is related with UUTD which means determining the bladder urodynamic characteristics may be important in deciding emphasis of the treatment.

Thus, according to our results, treatment resistant children with abnormal spinal imaging have statistically more UUTD than children with treatment responders. More detailed randomized studies are needed to enlighten this situation.

\section{Conclusion}

Many normal children presenting with intractable voiding dysfunction fail to normalize with urotherapy and medical management. Those who are resistant to the treatment are candidates for UUTD. Those patients usually have concomitant VUR and high pressure bladder. In tethered cord patients, upper urinary tract damage is encountered more frequently than patients with treatment resistant cases. 


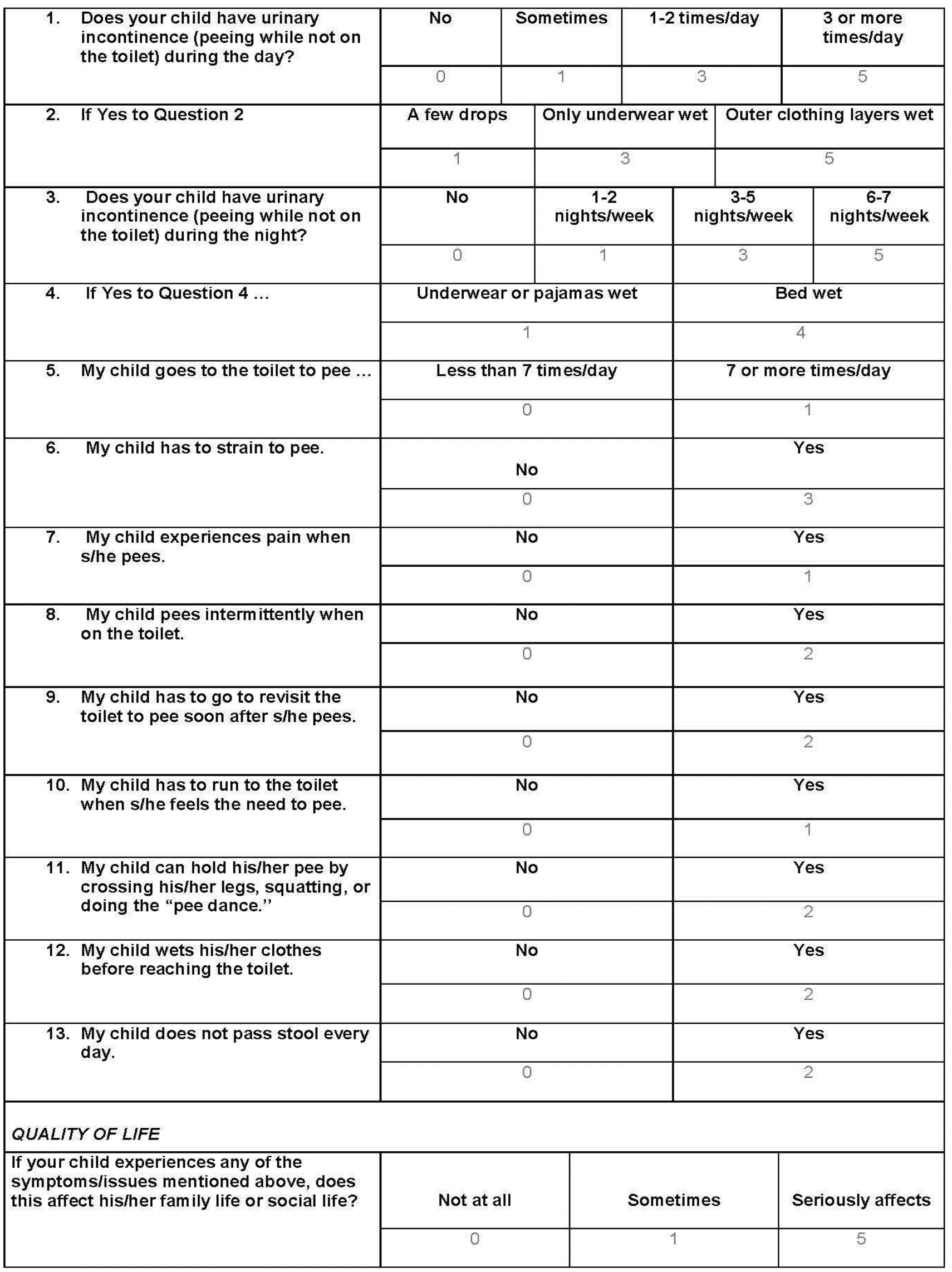

Figure 1: Pediatric Lower Urinary Tract Symptom Score (PLUTSS) [10] 


\section{References}

1. Hinman F Jr. Syndromes of vesical incoordination. Urol Clin North Am 1980;7:311-9.

2. Koff SA, Murtagh DS. The uninhibited bladder in children: effect of treatment on recurrence of urinary infection and on vesicoureteral reflux resolution. J Urol 1983;130:1138-41.

3. van Gool JD, Kuitjen RH, Donckerwolcke RA, Messer AP, Vijverberg M. Bladder-sphincter dysfunction, urinary infection and vesico-ureteral reflux with special reference to cognitive bladder training. Contrib Nephrol 1984;39:190-210.

4. Allen TD. Vesicoureteral reflux and the unstable bladder. J Urol 1985;134:1180.

5. Nijman JM, Butler RJ, van Gool JD, Yeung CK, Bower W. Conservative management of urinary incontinence in childhood. In: Abrams P, Cardozo L, Khoury S, Wein AJ, editors. Incontinence. Paris: Health Publication Ltd, 2002:540-2.

6. Wraige E, Borzyskowski M. Investigation of daytime wetting: when is spinal cord imaging indicated? Arch Dis Child 2002;87:151-5.

7. Vega PJ, Pascual LA. High-pressure bladder: an underlying factor mediating renal damage in the absence of reflux? BJU Int 2001;87:581-4.

8. Afshar K, Blake T, Jaffari S, MacNeily AE, Poskitt K, Sargent M. Spinal cord magnetic resonance imaging for investigation of nonneurogenic lower urinary tract dysfunction--can the yield be improved? J Urol 2007; 178:1748-50; discussion 501. doi: 10.1016/j.juro.2007.03.179

9. Santiago Medina L, al-Orfali M, Zurakowski D, Poussaint TY, DiCanzio J, Barnes PD. Occult lumbosacral dysraphism in children and young adults: diagnostic performance of fast screening and conventional MR imaging. Radiology 1999;211:767-71. doi: 10.1148/radiology.211.3.r99jn09767

10. Akbal C, Genc Y, Burgu B, Ozden E, Tekgul S. Dysfunctional voiding and incontinence scoring system: quantitative evaluation of incontinence symptoms in pediatric population. J Urol 2005;173:969-73. doi: 10.1097/01. ju.0000152183.91888.f6

11. Yildirim A, Uluocak N, Atilgan D, Ozcetin M, Erdemir F, Boztepe O. Evaluation of lower urinary tract symptoms in children exposed to sexual abuse. Urol J 2011;8:38-42.

12. Schneider D, Yamamoto A, Barone JG. Evaluation of consistency between physician clinical impression and 3 validated survey instruments for measuring lower urinary tract symptoms in children. J Urol 2011;186:261-5. doi: 10.1016/j.juro.2011.03.049

13. Farhat W, Bagli DJ, Capolicchio G, et al. The dysfunctional voiding scoring system: quantitative standardization of dysfunctional voiding symptoms in children. J Urol 2000;164:1011-5.

14. Neveus T, von Gontard A, Hoebeke P, et al. The standardization of terminology of lower urinary tract function in children and adolescents: report from the Standardisation Committee of the International Children's Continence Society. J Urol 2006;176:314-24. doi: 10.1016/S0022-5347(06)00305-3

15. Fernbach SK, Maizels M, Conway JJ. Ultrasound grading of hydronephrosis: introduction to the system used by the Society for Fetal Urology. Pediatr Radiol 1993;23:478-80.

16. Lebowitz RL, Olbing H, Parkkulainen KV, Smellie JM, Tamminen-Mobius TE. International system of radiographic grading of vesicoureteric reflux. International Reflux Study in Children. Pediatr Radiol 1985;15:105-9.
17. Dik P, Klijn AJ, van Gool JD, de Jong-de Vos van Steenwijk $\mathrm{CC}$, de Jong TP. Early start to therapy preserves kidney function in spina bifida patients. Eur Urol 2006;49:908-13. doi: 10.1016/j.eururo.2005.12.056

18. Vande Walle J, Rittig S, Bauer S, Eggert P, et al. Practical consensus guidelines for the management of enuresis. Eur J Pediatr 2012;171:971-83. doi: 10.1007/s00431-012-1687-7

19. van Gool JD, de Jong TP, Winkler-Seinstra P, et al. Multicenter randomized controlled trial of cognitive treatment, placebo, oxybutynin, bladder training, and pelvic floor training in children with functional urinary incontinence. Neurourol Urodyn 2014; 33: 482-7. doi: 10.1002/nau.22446

20. Austin PF, Bauer SB, Bower W, et al. The standardization of terminology of lower urinary tract function in children and adolescents: Update report from the standardization committee of the International Children's Continence Society. Neurourol Urodyn 2016;35:471-81. doi: 10.1002/nau.22751

21. Gammie A, Clarkson B, Constantinou C, et al. International Continence Society guidelines on urodynamic equipment performance. Neurourol Urodyn 2014;33:370-9. doi: 10.1002/nau.22546

22. Pippi Salle JL, Capolicchio G, Houle AM, et al. Magnetic resonance imaging in children with voiding dysfunction: is it indicated? J Urol 1998;160:1080-3.

23. Arikan N, Soygur T, Selcuki M, Erden I, Gogus O. Role of magnetic resonance imaging in children with voiding dysfunction: retrospective analysis of 81 patients. Urology 1999;54:157-60; discussion 60-1.

24. Schulman SL, Quinn CK, Plachter N, Kodman-Jones C. Comprehensive management of dysfunctional voiding. Pediatrics 1999;103:E31.

25. Curran MJ, Kaefer M, Peters C, Logigian E, Bauer SB. The overactive bladder in childhood: long-term results with conservative management. J Urol 2000;163:574-7.

26. Wiener JS, Scales MT, Hampton J, King LR, Surwit R, Edwards CL. Long-term efficacy of simple behavioral therapy for daytime wetting in children. J Urol 2000;164:78690.

27. Hsieh MH, Perry V, Gupta N, Pearson C, Nguyen HT. The effects of detethering on the urodynamics profile in children with a tethered cord. J Neurosurg 2006;105:391-5. doi: 10.3171/ped.2006.105.5.391

28. Stone JJ, Rozzelle CJ, Greenfield SP. Intractable voiding dysfunction in children with normal spinal imaging: predictors of failed conservative management. Urology 2010;75:161-5. doi: 10.1016/j.urology.2009.06.100

29. Seki N, Akazawa K, Senoh K, et al. An analysis of risk factors for upper urinary tract deterioration in patients with myelodysplasia. BJU Int 1999;84:679-82.

30. Bael A, Lax H, de Jong TP, et al. The relevance of urodynamic studies for Urge syndrome and dysfunctional voiding: a multicenter controlled trial in children. J Urol 2008;180:148693; discussion 94-5. doi: 10.1016/j.juro.2008.06.054

31. Tanaka H, Matsuda M, Moriya K, Mitsui T, Kitta T, Nonomura K. Ultrasonographic measurement of bladder wall thickness as a risk factor for upper urinary tract deterioration in children with myelodysplasia. J Urol 2008;180:312-6; discussion 6 . doi: $10.1016 /$ j.juro.2008.03.062

32. Tarcan T, Sekerci CA, Akbal C, et al. Is $40 \mathrm{~cm} \mathrm{H} 2 \mathrm{O}$ detrusor leak point pressure cut-off reliable for upper urinary tract protection in children with myelodysplasia? Neurourol Urodyn 2016 [Epub ahead of print]. doi: 10.1002/nau.23017. 